\title{
A possible role of ground-based microorganisms on cloud formation in the atmosphere
}

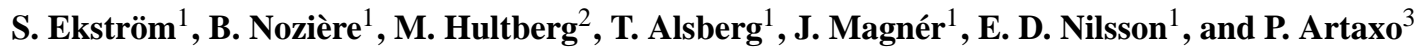 \\ ${ }^{1}$ Department of Applied Environmental Science (ITM), Svante Arrhenius väg 8, Stockholm University, \\ 10691 Stockholm, Sweden \\ ${ }^{2}$ Department of Horticulture, Swedish University of Agricultural Sciences, Alnarp, Sweden \\ ${ }^{3}$ Department of Physics, University of São Paolo, São Paolo, Brazil
}

Received: 26 August 2009 - Published in Biogeosciences Discuss.: 26 October 2009

Revised: 21 January 2010 - Accepted: 25 January 2010 - Published: 29 January 2010

\begin{abstract}
The formation of clouds is an important process for the atmosphere, the hydrological cycle, and climate, but some aspects of it are not completely understood. In this work, we show that microorganisms might affect cloud formation without leaving the Earth's surface by releasing biological surfactants (or biosurfactants) in the environment, that make their way into atmospheric aerosols and could significantly enhance their activation into cloud droplets.

In the first part of this work, the cloud-nucleating efficiency of standard biosurfactants was characterized and found to be better than that of any aerosol material studied so far, including inorganic salts. These results identify molecular structures that give organic compounds exceptional cloud-nucleating properties. In the second part, atmospheric aerosols were sampled at different locations: a temperate coastal site, a marine site, a temperate forest, and a tropical forest. Their surface tension was measured and found to be below $30 \mathrm{mN} / \mathrm{m}$, the lowest reported for aerosols, to our knowledge. This very low surface tension was attributed to the presence of biosurfactants, the only natural substances able to reach to such low values.

The presence of strong microbial surfactants in aerosols would be consistent with the organic fractions of exceptional cloud-nucleating efficiency recently found in aerosols, and with the correlations between algae bloom and cloud cover reported in the Southern Ocean. The results of this work also suggest that biosurfactants might be common in aerosols and thus of global relevance. If this is confirmed, a new role for microorganisms on the atmosphere and climate could be identified.
\end{abstract}

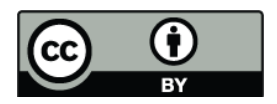

Correspondence to: B. Nozière (barbara.noziere@itm.su.se)

\section{Introduction}

Clouds play important roles in the atmosphere, the hydrological cycle, and climate. They constitute the largest cooling contribution to climate, but also the one containing the largest uncertainties (Foster et al., 2007a) because the nucleation of atmospheric aerosols into cloud droplets is still not completely understood. A possible contribution of the biosphere in these processes has been investigated for decades. One of these contributions was proposed as the CLAW hypothesis (Charlson et al., 1987, 2001), where the phytoplankton of the oceans emits dimethylsulfide (DMS), which is converted into sulfate salts in the atmosphere (Shaw, 1983), an efficient cloud-nucleating material (Charlson et al., 1987, 2001). But this link is now known to be rather small, as only a small fraction of DMS ( $25 \%)$ produces sulfates (Nilsson and Leck, 2002) and over $80 \%$ of the atmospheric sulfates are non-biological (Foster et al., 2007b). A possible role of airborne microorganisms on cloud formation has also been investigated. Some were found to be efficient ice nucleating agents (see for instance Schnell and Vali, 1972; Schnell, 1976; Bauer et al., 2003; Pratt et al., 2009). Their contribution to liquid clouds is also being debated (Moehler et al., 2007). However, for liquid clouds, the main nucleating materials currently known in aerosols are non-biological: inorganic salts, such sodium chloride or ammonium sulfate. Some organic compounds present in aerosols, such as organic acids (Facchini et al., 1999) and "Humic-Like Substances" or "HULIS" (Taraniuk et al., 2007), display some surface-active properties enhancing the formation of cloud droplets. But their effect is modest and none of the organic compounds identified until now in aerosols displayed better Cloud Condensation Nuclei properties (or "CCN" properties) than inorganic salts (McFiggans et al., 2006).

Published by Copernicus Publications on behalf of the European Geosciences Union. 
In this work, rather than studying the role of airborne microorganisms in the formation of cloud droplets we study the role of substances that are produced by some microorganisms at the Earth's surface and released in the environment, biosurfactants. Unlike the microorganisms these substances could make their way into sub-micron aerosol particles, which are important for cloud droplet nucleation. They would thus allow microorganisms to affect cloud formation without leaving the Earth's surface. In a first part of this work, the CCN properties of standards biosurfactants are studied and compared to those of inorganic salts. In a second part, the presence of biosurfactants in real aerosol samples and their effect on their surface tension is investigated.

\section{Experimental}

\subsection{Biosurfactant standards}

The first part of this work focused on characterizing the CCN efficiency of standard biosurfactants. Three different classes of biosurfactants were studied: rhamnolipids, galactolipids (mono- and di-galactosyl diacylglyceride), and a lipopeptide, (surfactin). Most biosurfactants have to be extracted from microorganisms. The known rhamnolipid sample JBR425 (Jeneil Biosurfactant Company, USA) used in our study was provided by Dr. Wang, PEER Centre, California Institute of Technology, USA (extract 1). Its composition is described in Wang et al. (2007). Another biosurfactant extract (extract 2) isolated from an environmental strain of $P$. aeruginosa was also studied (Hultberg et al., 2008). The extraction was performed as described in Zhang and Miller (1992). Monogalactosyl diacylglyceride ( $95 \%)$, digalactosyl diacylglyceride ( $\geq 95 \%)$, and surfactin ( $\geq 98 \%)$ were purchased from Aldrich.

\subsection{Aerosol sampling}

For the second part of the work, aerosols were sampled at Aspvreten, Sweden (forested/coastal region), $58^{\circ} 48^{\prime} \mathrm{N}$ $17^{\circ} 23^{\prime} \mathrm{E}$, from April to May 2008; in the Stockholm Archipelago $\sim 20 \mathrm{~km}$ at sea, Sweden ("marine" sample), $59^{\circ} 47^{\prime} 5 \mathrm{~N} 19^{\circ} 30^{\prime} 5 \mathrm{E}$, in July 2007 during an algae bloom; in Hyytiälä, Finland (temperate forest), $61^{\circ} 85^{\prime} \mathrm{N} 24^{\circ} 28^{\prime} \mathrm{E}$, in July 2008; in the tropical forest, Brazil, $2^{\circ} 37^{\prime} \mathrm{N} 60^{\circ} 12^{\prime} \mathrm{W}$, in May 2008. The samples were taken on Quartz fiber filters using high-volume samplers, for a duration between 48 and $150 \mathrm{~h}$, corresponding to a total of $100-500 \mathrm{~m}^{3}$ of sampled air. For the marine samples, $150 \mathrm{~L}$ of seawater were sampled just below the sea-surface and the aerosols were generated by jet impact on the surface of this water in a stainless steal tank. This technique has been previously shown to produce aerosols physically and chemically similar to those emitted by the sea surface (Mårtensson et al., 2003; Facchini et al., 2008). Because the analyses required large amounts of aerosol material, the size fraction sampled at these sites was $\mathrm{PM}_{10}$, except in Aspvreten, where it was $\mathrm{PM}_{2.5}$.

\subsection{Sample extraction}

The filters were extracted in Milli-Q water at $4{ }^{\circ} \mathrm{C}$ and filtered through Millipore $0.45 \mu \mathrm{m}$ syringe filters. An absorbent, silicone, was added and rotated (20-25 rpm) for $24 \mathrm{~h}$. The amphiphilic fraction was extracted in methanol, dried, and diluted in MilliQ-water. For the surface tension measurements, 1 to 3 filters were extracted together. The efficiency of this extraction method and its specificity towards surface-active compounds was tested by measuring the surface tension of water extracts before and after the second extraction step (see Sect. 2.5 below).

\subsection{Chemical analysis}

In this work, chemical analyses are presented only for the identification of one of the microbial extracts (JBR425). These analyses were performed by tandem mass spectrometry (MSMS) with a Quadrupole Time-of-Flight Premier (Waters, Manchester, UK) mass spectrometer with an electrospray ion source. The microbial extract was introduced by direct infusion or following separation on an Acquity BEH C8 column fitted to an Acquity UPLC (Ultraperformance Liquid Chromatography) system (Waters, Milford, USA).

\subsection{Osmolality and surface tension measurements}

In the first part of this work, the CCN efficiency of standard substances was quantified by their Köhler curves, representing the water vapor pressure (or supersaturation $=$ water vapor in excess to saturation) necessary to activate particles made of these substances into cloud droplets. These curves were built point by point from solutions of these substances in water and their subsequent dilutions, following a method developed recently (Kiss and Hansson, 2004; Varga et al., 2007; Ekström et al., 2009). The surface tension was measured with a FTÅ 125 tensiometer and the osmolality with a KNAUER K - 7000 vapor pressure osmometer.

The surface tension curves for the aerosol samples in the second part of the work were obtained from the aerosol sample extracts and their further dilutions. The efficiency of the extraction method for surface-active compounds was verified by measuring the surface tension of some of these water extracts before and after the second extraction step. In all cases, this surface tension increased back to the value for pure water $(73 \mathrm{mN} / \mathrm{m})$ within uncertainties after the second extraction, confirming that most surface-active compounds had been removed from these mixtures. For instance, the water extracts from the Amazonian forest samples had an initial surface tension of $53.1 \mathrm{mN} / \mathrm{m}$, which increased back to $71.6 \mathrm{mN} / \mathrm{m}$ after the second extraction. And the water extracts from the Hyytiälä samples had a surface tension of $59.6 \mathrm{mN} / \mathrm{m}$, which increased to $71 \mathrm{mN} / \mathrm{m}$ after the second extraction step. The 
solutions obtained from the second extractions were those used to determine the surface tension curves, the original solutions corresponding to the largest concentrations and the lowest surface tensions on the curves. Control tests with "blank" samples were also performed to ensure that these measurements were free from artifacts from the extraction or from contamination of the filters during sampling. The extraction method itself did not lead to any artifacts, the surface tension obtained for blank filters being within $5 \%$ of the one of pure water, which was within the experimental uncertainties (Ekström et al., 2009). Only one blank filter displayed evidence for a small contamination, possibly due to bacterial growth on the sampler, but which affected the surface tension by less than $10 \%$. A systematic cleaning of the sampler was subsequently performed and no further contamination was observed.

\section{Results and discussion}

\subsection{Cloud-forming efficiency of standard biosurfactants}

A large variety of microorganisms are known to synthesize strong surfactants, or biosurfactants, that are present at their cell surface or released into the environment, and can reduce the surface tension of water from $73 \mathrm{mN} / \mathrm{m}$ to less than $30 \mathrm{mN} / \mathrm{m}$ (Hommel and Ratledge, 1993; Desai and Banat, 1997). The production of biosurfactants is however not common to all microorganisms, and the ability of some species rather than others to synthesize these substances, as well as their physiological functions, are still unclear. But while common biological material such as cell fragments, extracellular materials, and metabolites, all display some surfaceactive properties, only specific molecules are able to reduce the surface tension of water below $40 \mathrm{mN} / \mathrm{m}$ and qualify as biosurfactants (Hommel and Ratledge, 1993; Desai and Banat, 1997). These exceptional properties are of great interest for industrial applications, and artificial surfactants have been synthesized to try to match them. But the presence of artificial surfactants in natural environments and, in particular, in the aerosols samples studied in this work is unlikely.

The first part of this work focused on investigating the CCN efficiency of standard biosurfactants, chosen among the most common in the environment (Table 1):

- rhamnolipids, which are produced by Pseudomonas aeruginosa (Jarvis and Johnson, 1949), and belonging to the fluorescent pseudomonads, ubiquitous in the environment (Van der Kooij, 1979; Cho and Tedje, 2000; Bodour et al., 2003) and even in cloud and rainwater (Ahern et al., 2007),

- galactolipids (mono- and di-galactosyl diacylglyceride), which are common in freshwater and marine cyanobacteria (Merritt et al., 1991; Ikawa et al., 1994), such as those responsible for algae blooms (Shapiro, 1973), and
- lipopeptide (surfactin), produced by Bacillus subtilis, also common in the environment (Bodour et al., 2003).

In particular, the rhamnolipids studied in this work were from two different bacterial strains and extracted by slightly different techniques (see Sect. 2.1). They contained thus different mixtures of mono- and dirhamnolipids giving them slightly different physico-chemical properties (Benincasa et al., 2004). The molecular structure of the surfactants contained in these extracts was confirmed by Electrospray Ionization High Resolution Hybrid Mass Spectrometry. For instance, Fig. 1 shows the MSMS spectra obtained from the extract of JBR425 and displaying the characteristic patterns of rhamnolipids (Mw: 504.330): the negative ion mode provided the pseudomolecular ion $[\mathrm{M}-\mathrm{H}]^{-}$at $m / z=503.33$, fragment ions of the fatty acid moiety (hydrophobic chain) at $m / z=169.12$, and fragmentations of the rhamnose moiety (hydrophilic part) at $m / z=163.07$.

The cloud-forming efficiency of the standard microbial surfactants was determined from their Köhler curves, representing the water vapor (expressed as the ratio over the saturation pressure, supersaturation) necessary to activate particles made of these substances into cloud droplets. As microbial surfactants are always mixed with water-soluble compounds in the environment, produced by the microorganisms or present as nutrients (Hommel and Ratledge, 1993; Desai and Banat, 1997; Benincasa et al., 2004), the most realistic description of their $\mathrm{CCN}$ properties was given by mixing them with small amounts of sodium chloride or ammonium sulfate $(\sim 0.07-0.2 \mathrm{M})$. The Köhler curves obtained for these mixtures were determined as described in Sect. 2.5, and the results are shown on Fig. 2 for an initial ("dry") particle of diameter $60 \mathrm{~nm}$. It is clear on Fig. 2 that all the curves for the standard biosurfactants have a critical supersaturation (maximum) lower than those for sodium chloride and ammonium sulfate: $\mathrm{Sc}=0.08-0.21$, compared with $\mathrm{Sc}=0.25$ for $\mathrm{NaCl}$, and 0.34 for $\left(\mathrm{NH}_{4}\right)_{2} \mathrm{SO}_{4}$. To our knowledge it is the first time that specific organic molecules are shown to have better cloud-forming efficiencies than inorganic salts (McFiggans et al., 2006). These results are important because they identify the molecular structures that give to organic compounds exceptional CCN properties, and which should be investigated in atmospheric aerosols. The Köhler curves also imply that aerosol particles containing these substances would nucleate into cloud droplets at lower supersaturation than inorganic salt particles or that, at similar supersaturation, would form larger cloud droplets. These larger droplets would be more prone to precipitation, thereby affecting the optical properties of the clouds and, at large scale, their contribution to climate (see for instance Ervens et al., 2005).

\subsection{Presence of biosurfactants in atmospheric aerosols}

To investigate the presence of biosurfactants in atmospheric aerosols, aerosols samples were collected at the four locations described in Sect. 2.2 (Aspvreten, Sweden, Stockholm 
Table 1. Standard microbial substances studied in this work, and examples of microorganisms producing them and their occurrences in the environment.

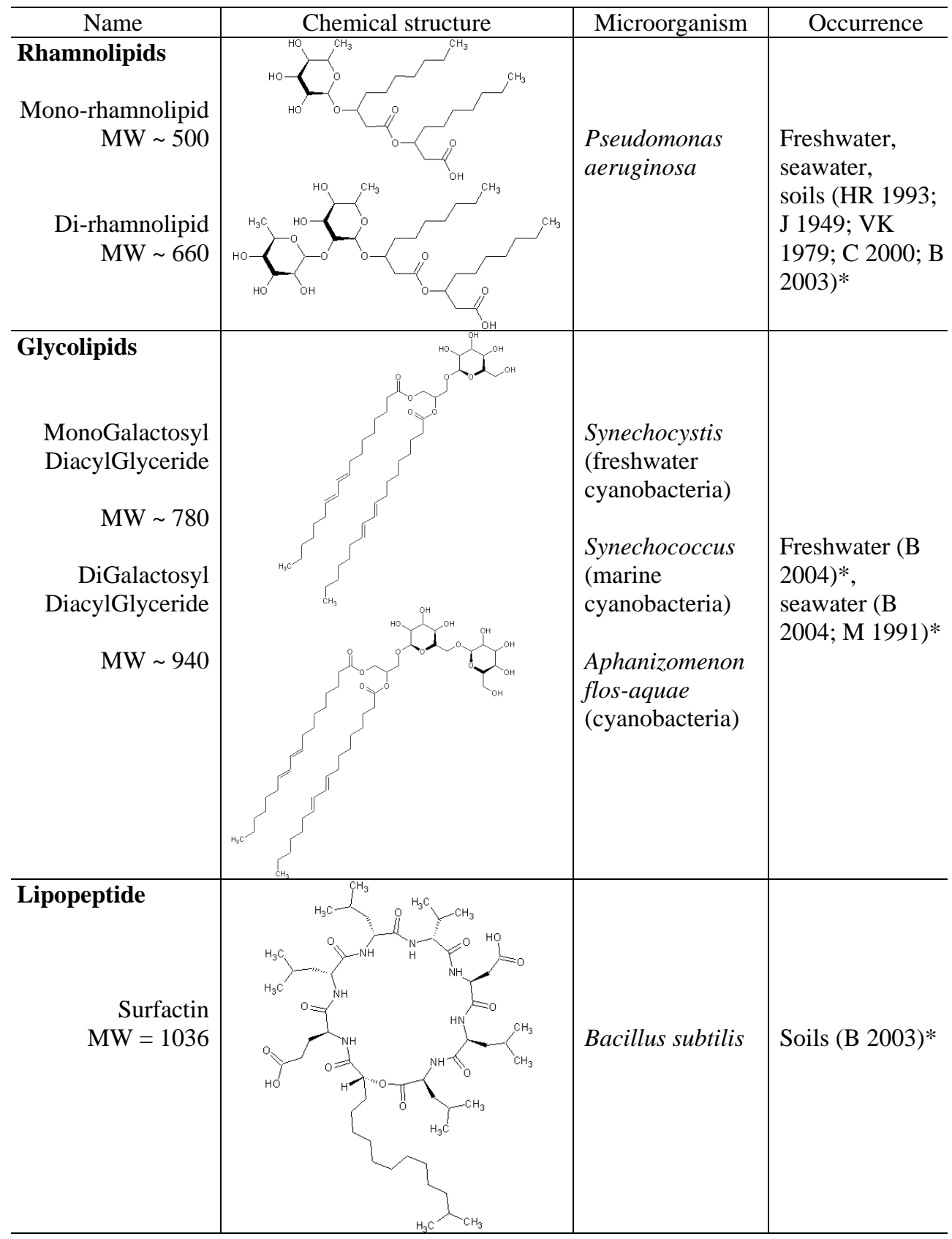

* HR 1993: Hommel and Ratledge, 1993; J 1949: Jarvis and Johnson, 1949; VK 1979: Van der Kooij, 1979; C 2000: Cho and Tedje, 2000; B 2003: Bodour et al., 2003; B 2004: Benincasa et al., 2004; M 1991: Merritt et al., 1991.

Archipelago, Sweden, Hyytiälä, Finland, and near Manaus, Brazil) and their amphiphilic fraction was extracted as described in Sect. 2.3. LC/MSMS analyses were first applied to the aerosol extracts but the sensitivity required for the identification of microbial surfactants was not sufficient. Another approach had thus to be used. Since the objective of this investigation was twofold, 1) evidencing the presence of biosurfactants in the samples, and 2) showing their effects on the surface tension of the aerosols, the surface tension of these aerosol samples was investigated, to answer both questions at the same time. Surface tension curves were thus determined for these aerosol extracts, and compared to those of 


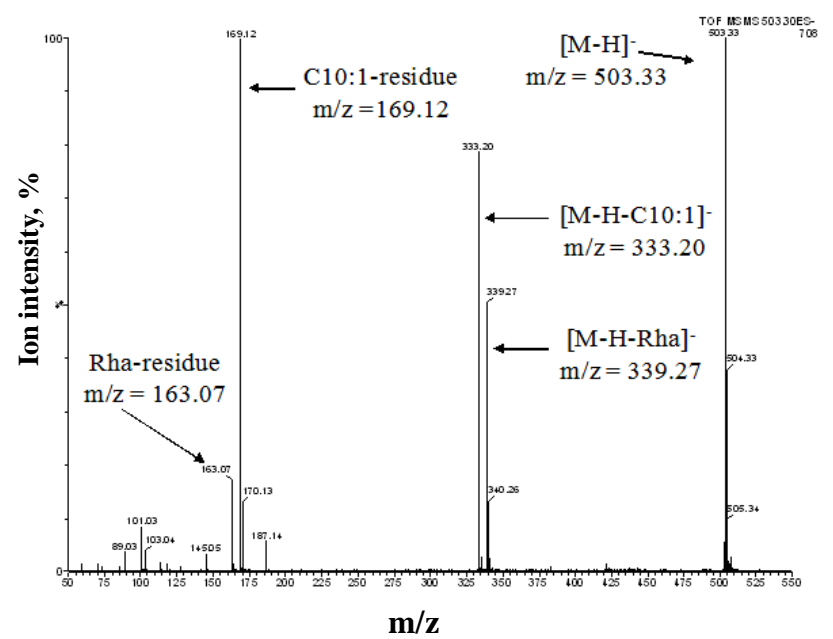

Fig. 1. MSMS spectrum of the reference rhamnolipid JBR425 (Mw: 504.330) in negative ion mode: Parent ion $(\mathrm{m} / \mathrm{z}=503.33)$, fragment ions of the rhamnose moiety, "Rha-residue" $(\mathrm{m} / \mathrm{z}=163.07)$, and of the fatty acid moiety "C10:1-residue", $(\mathrm{m} / \mathrm{z}=169.12)$.

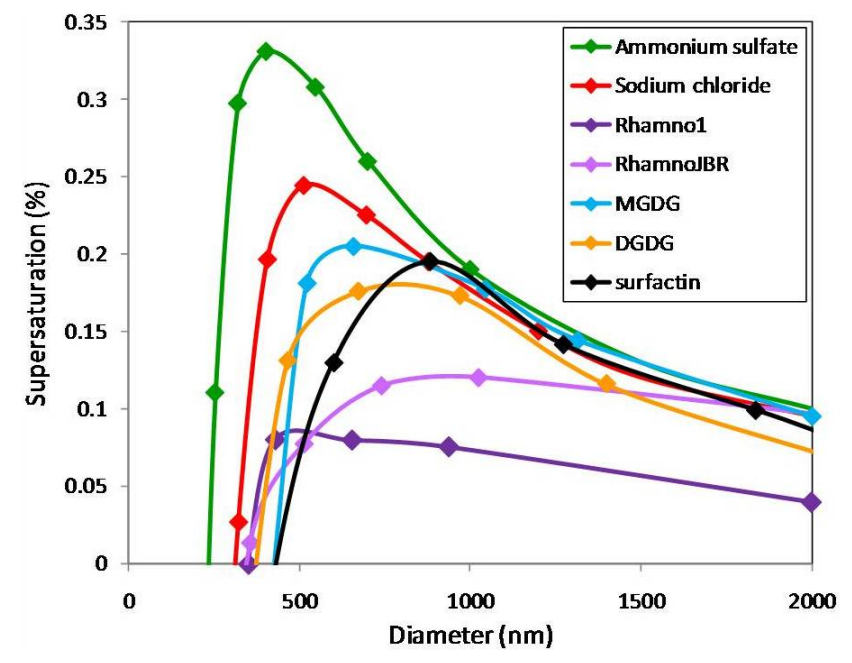

Fig. 2. Köhler curves for inorganic salts and standard microbial surfactants in aqueous solutions of sodium chloride 0.07-0.2 M (dry diameter $=60 \mathrm{~nm}$ ). sodium chloride: red; ammonium sulfate: green; monogalactosyl diacylglyceride ("MGDG"): pale blue; digalactosyl diacylglyceride ("DGDG"): orange; surfactin: black; rhamnolipid (extract 1, "Rhamno1"): dark purple (this curve with ammonium sulfate instead of sodium chloride); rhamnolipid (extract 2, "RhamnoJBR"): pale purple.

sodium chloride, ammonium sulfate, organic acids (malonic acid), HULIS, and the standard biosurfactants studied in the first part of the work. The results are presented in Fig. 3.

First, comparing the curves for the standard compounds between them (curves with full triangles) shows the unique features of the microbial surfactants and their dramatic effects on the surface tension:

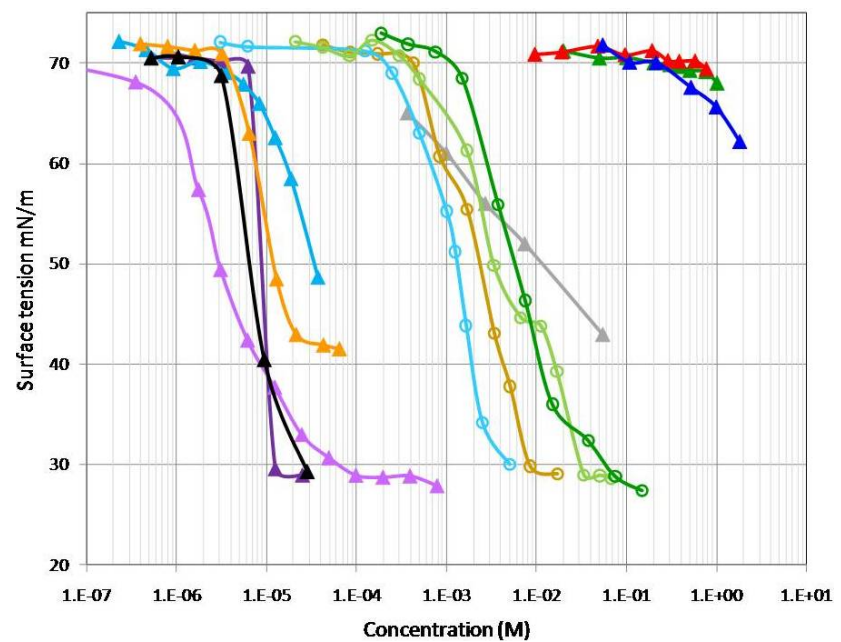

Fig. 3. Effect on the surface tension of water of different standard compounds as function of their molar concentration (curves with filled triangles): sodium chloride: red; ammonium sulfate: green; malonic acid: dark blue; HULIS: grey; monogalactosyl diacylglyceride: pale blue; digalactosyl diacylglyceride: orange; surfactin: black; rhamnolipid (extract 1): dark purple; rhamnolipid (extract 2): pale purple. Comparison with the surface tension of aerosol sample extracts (curves with open circles): coastal site (Aspvreten, Sweden): brown; marine site during algae bloom (Sweden): clear blue; temperate forest (Hyytiälä, Finland): pale green; Amazonian forest (Manaus, Brazil): dark green.

- the very low surface tension values at large concentrations, less than $30 \mathrm{mN} / \mathrm{m}$ for some compounds,

- the very low concentrations necessary to achieve the minimum surface tension (3-5 orders of magnitude lower than the concentrations of HULIS or organic acids in aerosols),

- a sharp transition on the curves $(>20 \mathrm{mN} / \mathrm{m}$ for a factor 10 in concentration) contrasting with the gradual effects of the other compounds, such as HULIS or organic acids, on the surface tension.

As explained above, surface tension values of less than $40 \mathrm{mN} / \mathrm{m}$, such as obtained with the rhamnolipids and lipopeptide in this work, are typical of biosurfactants. And the higher value obtained with digalactosyl diacylglyceride, is a good illustration of the intermediate surface-active properties displayed by most biological molecules, but which do not necessarily qualify them as biosurfactants. The sharp transitions on these surface tension curves corresponded to the Critical Micelle Concentration (CMC), for which the surfactant molecules in solution arrange themselves in aggregates, or micelles, exposing their hydrophilic moieties to the solvent. The importance of an amphiphilic layer (micelles or inverted micelles) on aerosol particles has been discussed, however in a different context, in Ellison et al. (1999) and 
Dobson et al. (2000). The values of the CMC for the compounds studied here are $\sim 10 \mu \mathrm{M}$ for rhamnolipids (Desai and Banat, 1997), $13 \mu \mathrm{M}$ for digalactosyl diacylglycerol (Vishwanath et al., 1996), $24 \mu \mathrm{M}$ for surfactin (Desai and Banat, 1997). This implies that only a few tens of $\mu \mathrm{M}$ of biosurfactants would lower the surface tension of water to about $30 \mathrm{mN} / \mathrm{m}$. By contrast, $20 \mathrm{mM}\left(\sim 20 \mathrm{gL}^{-1}\right)$ of HULIS would only lower the surface tension to $45 \mathrm{mN} / \mathrm{m}$ (Taraniuk et al., 2007), and $10 \mathrm{M}$ of malonic acid would lower it to $50 \mathrm{mN} / \mathrm{m}$.

Note that at large concentrations (in particular beyond the $\mathrm{CMC}$ ) all surface tension curves should reach a plateau, as the maximum effect on the surface tension is achieved. The curves on Fig. 3 (and in the literature) that do not reach such a plateau indicate that the measurements were limited by experimental difficulties (usually, the inability to concentrate the samples enough) and that the actual minimum was not attained.

Comparing the curves for the standard compounds with those obtained with the aerosol extracts on Fig. 3 (curves with open circles) clearly show that the latter have the distinct signatures of microbial surfactants: a surface tension below $30 \mathrm{mN} / \mathrm{m}$ at high concentrations, and a sharp transition characteristic of micelle-forming surfactants. Their positions on the $\mathrm{x}$-axis in Fig. 3 are, however, arbitrary as the surfactant concentrations in these samples were unknown. These positions corresponded approximately to the total organic concentrations in the samples. The relative position of the curves for the standard biosurfactants thus suggested that the concentrations of surfactants in the aerosol extracts could have been of the order of 100 to 10000 times lower than the total organic concentration. The very low surface tension values obtained with the aerosol samples were attributed to the presence of biosurfactants, because these compounds are the only natural substances able to have such strong effects on the surface tension (Hommel and Ratledge, 1993; Desai and Banat, 1997). A contamination of the samples or the measurements by artificial surfactants was unlikely as artificial surfactants require concentrations several orders of magnitude larger than biosurfactants to achieve the same surface tension effects. For instance, sodium dodecyl sulfate, the most common detergent, would require $8 \mathrm{mM}$ to lower the surface tension to $40 \mathrm{mN} / \mathrm{m}$ (Williams et al., 1955), which would be comparable to the total organic content of the aerosols. A contribution of airborne microorganisms to the aerosol samples collected was also expected to be negligible because the latter represent a very small fraction of the aerosol mass in the atmosphere ( $\ll 1 \%$, Pósfai et al., 2003; Harrison et al., 2005), only some of them produce surfactants (Ahern et al., 2007).

The volumes extracted from the aerosol samples also gave some information on the effect of these surfactants on the surface tension of the aerosols. These volumes were larger $(30-100 \mu \mathrm{L})$ than the initial aerosol samples $(<10 \mu \mathrm{L}$, assuming a maximum aerosol loading of $100 \mathrm{\mu g} \mathrm{m}^{-3}$ ) implying that the extracts were diluted compared to the aerosols and, therefore, that the lowest surface tension reported here are upper limits of those of the aerosols collected (at least, in average). The surfactants were thus concentrated enough in the aerosols to reduce dramatically their surface tension, or at least the one of some particles in them. As the surface tension curves for the aerosol samples were similar to those of the standard biosurfactants, they are also likely to have similar Köhler curves and to be activated into cloud droplets at lower water vapor than particles made of other material, including inorganic salts.

\section{Discussion and conclusion}

The first part of this work established that biosurfactants such as rhamnolipids, galactolipids, or lipopeptides would be better $\mathrm{CCN}$ material than any aerosol material studied until now, including inorganic salts. These exceptional $\mathrm{CCN}$ properties result both from the dramatic effect of these molecules on the surface tension of water $(<30 \mathrm{mN} / \mathrm{m})$ and to the extremely small concentrations necessary to achieve them (tens of $\mu \mathrm{M}$ ). These results identify thus molecular structures providing organic compounds with exceptional surface-active and CCN properties, which should be investigated in aerosols.

In a second part, the surface tension of aerosol samples from different origins was measured and found to be lower than $30 \mathrm{mN} / \mathrm{m}$, which reflected the surface tension of the aerosols themselves. To our knowledge, this is the lowest surface tension reported for aerosols until now. This very low surface tension was attributed to the presence of biosurfactants in these aerosols, as these compounds are the only natural substances having such strong surface tension effects.

The presence of such powerful surfactants in atmospheric aerosols would be consistent with the organic fractions of better CCN efficiency than ammonium sulfate recently identified in biomass burning aerosols (Asa-awuku et al., 2008). As mentioned in introduction, these biological substances, unlike the microorganisms themselves, could make their way into sub-micron aerosol particles, which are important for cloud formation. The presence of biosurfactants in submicron aerosol particles $\left(\mathrm{PM}_{1}\right)$ is currently being investigated. As biosurfactants are released by microorganisms in the environment, they are likely to be mixed with other biological materials, such as sugars (Kourtchev et al., 2005), amino acids (Zhang and Anastasio, 2003; Yang et al., 2005), or plant wax (Lin and Lee, 2004), which have all been found in $\mathrm{PM}_{1}$ or $\mathrm{PM}_{2.5}$ aerosol particles. Biosurfactants could thus be transported together with these materials into the aerosols. Marine biosurfactants could be transported by bubble bursting or wave breaking into sub-micron particles (for instance, Mårtensson et al., 2003). These biosurfactants would thus allow microorganisms to affect cloud formation without leaving the surface of the Earth. 
The results of this work suggest that the presence of biosurfactants could make aerosols more CCN-efficient than inorganic salt particles. This, in turn, would affect the onset of precipitation and the optical properties of the clouds, which are essential for climate. Modeling studies have shown that the effects of surface-active organic compounds on cloud formation would be especially important for low-level clouds or air masses with small vertical updraft (Ervens et al., 2005). However, none of the previous modeling studies expected organic compounds to have the dramatic effect on the surface tension of aerosols evidenced in this work $(-\Delta \sigma / \sigma>58 \%)$. The contribution of biosurfactants to cloud formation remains thus to be investigated. The very small concentrations at which biosurfactants operate were not expected in previous model studies either. These very low concentrations and the limited mixing of these biosurfactants with the bulk aerosol contents would also be consistent with the apparent lack of correlation between $\mathrm{CCN}$ numbers and aerosol chemical composition.

A role of microbial substances on cloud formation would be consistent with the correlations between cloud cover and algae bloom reported for the Southern Ocean (Meskhidze and Nenes, 2006). The very low surface tensions obtained with all the aerosol samples in this work would also be consistent with the ubiquitous presence of surfactant-producing microorganisms on Earth, even in the most hostile environments (Bodour et al., 2003; Perfumo et al., 2006; Gulati et al., 2008), and suggest the global relevance of biosurfactants for aerosols. If the role of biosurfactants in cloud formation is confirmed, new links between the biosphere, atmospheric processes, the hydrological cycle, and climate would be identified, where the responses of the microbial populations to climate change would constitute new climate feedbacks. Confirming a role of microorganisms on cloud formation would bring other interesting questions, such as whether this role is fortuitous or a survival strategy developed by the microorganisms to control the availability of water in their environment.

Acknowledgements. Hans Karlsson (Stockholm Univ.) is gratefully acknowledged for the sampling in Aspvreten, Hans Wegmann for the cruise in the Stockholm Archipelago and the marine samples, and Janne Levula (Univ. of Helsinki) for the aerosol sampling in Hyytiälä, Finland. The European Commission is acknowledged for funding through a Marie Curie Chair (BN), an International Reintegration Grant (BN), and the research programs EUSAAR (sampling in Hyytiälä) and NOMIRACLE (development of extraction techniques). The Swedish Research Council (VR) and the Swedish Research Council for Environment, Agricultural science and spatial planning (FORMAS) are acknowledged for funding. G. Feingold (NOAA, USA) and R. M. Maier (Univ. of Arizona, USA) are gratefully acknowledged for their useful comments on the manuscript.

Edited by: C. Spirig

\section{References}

Ahern, H. E., Walsh, K. A., Hill, T. C. J., and Moffett, B. F.: Fluorescent pseudomonads isolated from Hebridean cloud and rain water produce biosurfactants but do not cause ice nucleation, Biogeosciences, 4, 115-124, 2007, http://www.biogeosciences.net/4/115/2007/.

Asa-Awuku, A., Sullivan, A. P., Hennigan, C. J., Weber, R. J., and Nenes, A.: Investigation of molar volume and surfactant characteristics of water-soluble organic compounds in biomass burning aerosol, Atmos. Chem. Phys., 8, 799-812, 2008, http://www.atmos-chem-phys.net/8/799/2008/.

Bauer, H., Giebl, H., Hitzenberg, R., Kasper-Giebl, A., Reschl, G., Zibushka, F., and Puxbaum, H.: Airborne bacteria as cloud condensation nuclei, J. Geophys. Res., 108, 4658, doi:10.1029/2003JD003545, 2003.

Benincasa, M., Abalos, A., Oliveira, I., and Manresa, A.: Chemical structure, surface Properties and biological activities of the biosurfactant produced by Pseudomonas aeruginosa LBI from soapstock, Antonie van Leeuwenhoek, 85, 1-8, 2004.

Bodour, A. A., Drees, K. P., and Maier, R. M.: Distribution of biosurfactant-producing Bacteria in undisturbed and contaminated arid Southwestern soils, Appl. Environ. Microbiol., 69, 3280-3287, 2003.

Charlson, R. J., Lovelock, J. E., Andreae, M. O., and Warren, S. G.: Oceanic phytoplankton, atmospheric sulphur, cloud albedo and climate, Nature, 326, 655-661, 1987.

Charlson, R. J., Seinfeld, J. H., Nenes, A., Kulmala, M., Laaksonen, A., and Facchini, M. C.: Reshaping the Theory of Cloud Formation, Science, 292, 2025-2026, 2001.

Cho, J. C., and Tiedje, J. M.: Biogeography and Degree of Endemicity of Fluorescent Pseudomonas Strains in Soil, Appl. Environ. Microbiol., 66, 5448-5456, 2000.

Desai, J. D. and Banat, I. M.: Microbial production of surfactants and their commercial Potential, Microbiol. Mol. Biol. R., 61, 4764, 1997.

Dobson, C. M., Ellison, G. B., Tuck, A. F., and Vaida, V.: Atmospheric aerosols as prebiotic chemical reactors, P. Natl. Acad. Sci. USA, 97, 11864-11868, 2000.

Ekström, S., Nozière, B., and Hansson, H.-C.: The Cloud Condensation Nuclei (CCN) properties of 2-methyltetrols and C3-C6 polyols from osmolality and surface tension measurements, Atmos. Chem. Phys., 9, 973-980, 2009, http://www.atmos-chem-phys.net/9/973/2009/.

Ellison, G. B., Tuck, A. F., and Vaida, V.: Atmospheric processing of organic aerosols, J. Geophys. Res., 101, 11633-11641, 1999.

Ervens, B., Feingold, G., and Kredenweis, S. M.: Influence of water-soluble organic carbon on cloud drop number concentration, J. Geophys. Res., 110, D18211, doi:10.1029/2004JD005634, 2005.

Facchini, M. C., Mircea, M., Fuzzi, S., and Charlson, R. J.: Cloud albedo enhancement by surface-active organic solutes in growing droplets, Nature, 410, 257-259, 1999.

Facchini, M. C., Rinaldi, M., Decesari, S., Carbone, C., Finessi, E., Mircea, M., Fuzzi, S., Ceburnis, D., Flanagan, R., Nilsson, E. D., de Leeuw, G., Martino, M., Woeltjen, J., and O'Dowd, C. D.: Primary submicron marine aerosol dominated by insoluble organic colloids and Aggregates, Geophys. Res. Lett., 35, L17814, doi:10.1029/2008GL034210, 2008.

Foster, P., Ramaswamy, V., Artaxo, P., et al.: Changes in atmo- 
spheric constituents and in radiative forcing, in: Climate Change 2007: The Physical Science Basis, edited by: Solomon, S., Qin, D., Manning, M., et al., Cambridge University Press, Cambridge, UK, a) 171-172; b) p. 160, 2007.

Gulati, A., Rahi, P., and Vyas, P.: Characterization of phosphatesolubilizing fluorescent Pseudomonads from the rhizosphere of seabuckthorn growing in the cold deserts of Himalayas, Current Microbiol., 56, 73-79, 2008.

Harrison, R. M., Jones, A. M., Biggins, P. D. E., Pomeroy, N., Cox, C. S., Kidd, S. P., Hobman, J. L., Brown, N. L., and Beswick, A.: Climate factors influencing bacterial count in background air samples, Int. J. Biometeorol., 4, 167-178, 2005.

Hommel, R. K. and Ratledge, C.: Biosynthetic mechanisms of low molecular weight surfactants and their precursor molecules, in Biosurfactants, edited by: Kosaric, N., Marcel Dekker, New York, USA, p. 5, 1993.

Hultberg, M., Bergstrand, K. J., Khalil, S., and Alsanius, B.: Production of biosurfactants and antibiotics by fluorescent pseudomonads isolated from a closed hydroponic system equipped with a slow filter, Antonie van Leeuwenhoek, 93, 373-380, 2008.

Ikawa, M., Sanser, J. J., and Haney, J. F.: Lipids of cyanobacterium Aphanizomenon flos-aquae and inhibition of Chlorella growth, J. Chem. Ecol., 20, 2429-2436, 1994.

Jarvis, F. G. and Johnson M. J.: A Glyco-lipide produced by Pseudomonas aeruginosa, J. Am. Chem. Soc., 71, 4124-4126, 1949.

Kiss, G. and Hansson, H.-C.: Application of osmolality for the determination of water activity and the modelling of cloud formation, Atmos. Chem. Phys. Discuss., 4, 7667-7689, 2004, http://www.atmos-chem-phys-discuss.net/4/7667/2004/.

Kourtchev, I., Ruuskanen, T., Maenhaut, W., Kulmala, M., and Claeys, M.: Observation of 2-methyltetrols and related photooxidation products of isoprene in boreal forest aerosols from Hyytiäl "a, Finland, Atmos. Chem. Phys., 5, 2761-2770, 2005, http://www.atmos-chem-phys.net/5/2761/2005/.

Lin, J. J. and Lee, L.-C.: Characterization of $n$-alkanes in urban submicron aerosol particles $\left(\mathrm{PM}_{1}\right)$, Atmos. Environ., 38, 29832991, 2004.

McFiggans, G., Artaxo, P., Baltensperger, U., Coe, H., Facchini, M. C., Feingold, G., Fuzzi, S., Gysel, M., Laaksonen, A., Lohmann, U., Mentel, T. F., Murphy, D. M., O'Dowd, C. D., Snider, J. R., and Weingartner, E.: The effect of physical and chemical aerosol properties on warm cloud droplet activation, Atmos. Chem. Phys., 6, 2593-2649, 2006,

http://www.atmos-chem-phys.net/6/2593/2006/.

Merritt, M. V., Rosenstein, S. P., Loh, C., Hui-Sui Chou, R., and Allen, M. M.: A comparison of the major lipid classes and fatty acid composition of marine unicellular cyanobacteria freshwater species, Arch. Microbiol., 155, 107-113, 1991.

Meskhidze, N. and Nenes, A.: Phytoplankton and cloudiness in the Southern ocean, Science, 314, 1419-1423, 2006.

Mhler, O., DeMott, P. J., Vali, G., and Levin, Z.: Microbiology and atmospheric processes: the role of biological particles in cloud physics, Biogeosciences, 4, 1059-1071, 2007, http://www.biogeosciences.net/4/1059/2007/.

Mårtensson, E. M., Nilsson, E. D., de Leeuw, G., Cohen, L. H., and Hansson, H. C.: Laboratory simulations and parameterization of the primary marine aerosol production, J. Geophys. Res., 108, 4297, doi:10.1029/2002JD002263, 2003.
Nilsson, E. D. and Leck, C.: A pseudo-Lagrangian study of the sulfur budget in the remote Arctic marine boundary layer, Tellus, 54B, 213-230, 2002.

Perfumo, A., Banat, I. M., Canganella, F., Marchant, R.: Rhamnolipid production by a novel thermophilic hydrocarbon-degrading Pseudomonas aeruginosa AP02-1, Appl. Microbiol. Biotechnol., 72, 132-138, 2006.

Pósfai, M., Li, J., Anderson, J. R., and Buseck, P. R.: Aerosol bacteria over the Southern Ocean during ACE-1, Atmos. Res., 66, 231-240, 2003.

Pratt, K., DeMott, P. J., French, J. R., Wang, Z., Westphal, D. L., Heymsfield, A. J., Twohy, C. H., Prenni, A. J., and Prather, K. A.: In situ detection of biological particles in cloud ice-crystals, Nature Geosci., 2, 398-401, 2009.

Schnell, R. C. and Vali, G.: Atmospheric ice nuclei from decomposing vegetation, Nature, 236, 163-167, 1972.

Schnell, R. C.: Bacteria acting as ice nucleants at temperatures approaching $-1{ }^{\circ} \mathrm{C}$, B. Am. Meteorol. Soc., 57, 1356-1357, 1976.

Shapiro, J.: Blue-Green Algae: Why they become dominant, Science, 179, 382-384, 1973.

Shaw, G. E.: Biocontrolled thermostasis involving the sulfur cycle, Climate Change, 5, 297-303, 1983.

Taraniuk, I., Graber, E. R., Kostinski, A., and Rudich, Y.: Surfactant properties of atmospheric and model humiclike substances (HULIS), Geophys. Res. Lett., 34, L16807, doi:10.1029/GL029576, 2007.

Van der Kooij, D.: Characterization and classification of fluorescent pseudomonads isolated from tap water and surface water, Antonie van Leeuwenhoek, 45, 225-240, 1979.

Varga, Z., Kiss, G., and Hansson, H.-C.: Modelling the cloud condensation nucleus activity of organic acids on the basis of surface tension and osmolality measurements, Atmos. Chem. Phys., 7, 4601-4611, 2007, http://www.atmos-chem-phys.net/7/4601/2007/.

Vishwanath, B. S., Eichenberger, W., Frey, F. J., and Frey, B. M.: Interaction of plant lipids with $14 \mathrm{kDa}$ phospholipase A2 enzymes, Biochem. J., 320, 93-99, 1996.

Wang, Q., Fang, X., Bai, B., Liang, X., Shuler, P. J., Goddard, W. A., and Tang, Y.: Engineering bacteria for production of rhamnolipid as an agent for enhanced oil recovery, Biotechnol. Bioeng., 98, 842-853, 2007.

Williams, R. J., Philips, J. N., and Mysels, K. J.: The critical micelle concentration of sodium lauryl sulphate at $25^{\circ} \mathrm{C}$, T. Faraday Soc., 51, 728-737, 1955.

Yang, H., Yu, J. Z., Ho, S. S. H., Xu, J., Wu, W. -S., Wan, C. H., Wang, X., Wang, X., and Wang, L.: The chemical composition of inorganic and carbonaceous materials in $\mathrm{PM}_{2.5}$ in Nanjing, China, Atmos. Environ., 39, 3735-3749, 2005.

Zhang, Q. and Anastasio, C.: Free and combined amino compounds in atmospheric fine particles $\left(\mathrm{PM}_{2.5}\right)$ and fog waters from Northern California, Atmos. Environ., 37, 2247-2258, 2003.

Zhang, Y. and Miller, R. M.: Enhanced octadecane dispersion and biodegradation by a Pseudomonas rhamnolipid surfactant, Appl. Environ. Microbiol., 58, 3276-3282, 1992. 